\title{
ПОКАЗАТЕЛИ СПЕЦИАЛЬНО-ДВИГАТЕЛЬНОЙ ПОДГОТОВЛЕННОСТИ В ХУДОЖЕСТВЕННОЙ ГИМНАСТИКЕ, ВЛИЯЮЩИЕ НА ДОСТИЖЕНИЕ СПОРТИВНОГО РЕЗУЛЬТАТА У ДЕВОЧЕК В ВОЗРАСТЕ 9-10 ЛЕТ
}

\section{INDICATORS OF SPECIAL AND MOTOR PREPAREDNESS IN RHYTHMIC GYMNASTICS AFFECTING \\ THE ACHIEVEMENT OF SPORTS RESULTS IN GIRLS AGED 9-10 YEARS OLD}

L. Shuvalova

A. Talan

N. Rodina

E. Kuznetsov

Summary: The purpose of this study is to establish the relationship between the indicators of the special motor abilities of young athletes and their sports results. To solve the set tasks, the indicators of specialmotor abilities in young athletes of 9-10 years old were analyzed using the computerized method «Raklik» of the cybersport platform «ClickStorm", aimed at assessing the accuracy of a simple visual-motor reaction (PMR); samples N.I. Ozeretsky on dynamic praxis and reciprocal hand coordination; distribution of attention based on a proofreading test (Anfimov's tables). The results of the study reliably confirm the relationship between the studied indicators characterizing the level of special-motor readiness and sports results among girls aged $9-10$ years in rhythmic gymnastics. The practical significance of the work lies in the fact that the indicators selected and analyzed in the course of the study reliably reflect the relationship between the level of special-motor readiness and the sports result of young gymnasts at the age of 9-10 years, due to which they can be used along with traditional means of complex pedagogical control in the course of sports preparation.

Keywords: rhythmic gymnastics, accuracy of a simple visual-motor reaction (PMR), N.I. Ozeretsky, dynamic praxis, proofreading test.
Шувалова Лилия Сергеевна

Асnирант, ФГБУ «Федеральный научный чентр физической культуры и спорта» (ФГБУФНЦ ВНИИФК)

lilia9292@mail.ru

талан Алексей Сергеевич

к.Х.н., дочент, Российский государственный университет физической культуры, спорта, молодёжи и туризма

(ГЦОЛИФК)

alex@click-storm.com

Родина Наталья Александровна

Тренер, РДОО Детский молодежный спортивный клуб «OPC»

rgforce@mail.ru

Кузнецов Евгений Валентинович

Консультант, РДОО Детский молодежный спортивный клуб «ФОРС»

lera24122001@gmail.com

Аннотация: Целью настоящего исследования является установить взаимосвязь между показателями специально-двигательных способностей юных спортсменок и их спортивным результатом. Для решения поставленных задач проанализированы показатели специально-двигательных способностей у юных спортсменок 9-10 лет при помощи компьютеризированной методики «Расклик» киберспортивной платформы «(lick-Storm», направленной на оценку точности простой зрительно-моторной реакции (ПЗМР); пробы Н.И. Озерецкого на динамический праксис и реципрокную координацию рук; распределения внимания на основе корректурной пробы (таблицы Анфимова). Результаты исследования достоверно подтверждают взаимосвязь между исследуемыми показателями, характеризующие уровень специально-двигательной подготовленности и спортивного результата у девочек в возрасте 9-10 лет в художественной гимнастике. Практическая значимость работы заключается в том, что избранные и проанализированные в ходе исследования показатели достоверно отражают взаимосвязь уровня специальнодвигательной подготовленности и спортивного результата юных гимнасток в возрасте 9-10 лет, благодаря чему могут быть использованы наряду с традиционными средствами комплексного педагогического контроля в ходе спортивной подготовки.

Ключевые слова: художественная гимнастика, точности простой зрительномоторной реакции (ПЗМР), проба Н.И. Озерецкого, динамический праксис, корректурная проба.

\section{Введение}

соответствии с данными научно-методической литературы к компонентам, характеризующим уровень специально-двигательной подготовленности в художественной гимнастике, традиционно принято относить не только двигательные способности спортсменок, но и уровень проявления психомоторных показателей. Однако в современных научных исследования, взаимосвязь показателей специально-двигательной 
подготовленности в художественной гимнастике и реализационной эффективности моторного потенциала спортсменок в соревнованиях освещены на этапах спортивного совершенствования и высшего спортивного мастерства, и лишь единичные исследования освещают особенности данного вида подготовленности у спортсменок на начальном и тренировочном этапах спортивной подготовки.

\section{^итературный обзор}

В соответствии с целями в области устойчивого развития сохраняют свою актуальность поиск новых методических приемов и направлений в сохранении хорошего здоровья и благополучия в том числе и в системе спортивной подготовки, где одним из критериев эффективности прохождения программы на тренировочном этапе является как и сохранение здоровья контингента занимающихся, так и благополучное решение задач этапа подготовки, в том числе и в виде достижения спортсменками максимального спортивного результата $[11,15]$.

По мнению отечественных и зарубежных специалистов в области художественной гимнастики наряду с общепризнанными видами подготовки - общей и специальной подготовки, технической, тактической, психологической, обуславливающими спортивный результат - специально-двигательная подготовленность является одним из ведущих компонентов, обуславливающим спортивный результат[8,19].

В исследованиях Е.С. Краевой, Е.В. Силич, Е.А. Шуголь, А.А. Соловьёва компоненты специально-двигательной подготовленностей такие как простая и сложная зрительно-моторные реакции, реакция на движущийся объект, особенности внимания и памяти, способность диф- ференцировать и воспроизводить заданные параметры движений являются одними из ключевых факторов, характеризующих исполнительское мастерство спортсменок и как следствие достижения ими максимального спортивного результата $[7,8,10,13,18,19]$.

«Сложность и красота движений, их выразительность и точность» - ведущие параметры исполнительского мастерства спортсменок, по мнению Н.А. Берштейна, Н.Г. Озолина, В.Н. Платонова для сложнокоординационных видах спорта являются важнейшими показателями технической подготовленности $[1,3,5]$. Следовательно, эффективная реализация исполнительского мастерства спортсменок основывается на овладении ими определенного уровня спортивно-технического мастерства в основе, которого заложено единство моторного, целевого и смыслового компонента психической деятельности спортсмена, благодаря чему достигается большая реализационная эффективность, т.е. достижение максимального спортивного результата $[4,5,17,18]$.

\section{Результаты и обсужление}

В настоящем исследовании приняли участие 19 спортсменок в возрасте 9-10 лет, проходящих спортивную подготовку на тренировочном этапе спортивной подготовки в Региональной детской общественной организации «Детский молодежный спортивный клуб «ФОРС», Москва. Оценивались показатели точности простой зрительно-моторной реакции с помощью специализированного ПО «Расклик», способность воспроизводить моторные программы (проба Н.И. Озерецкого), распределения внимания на основе корректурной пробы (таблицы Анфимова) (рисунок 1) [2,6,9,14].

Математический анализ исследуемых показателей

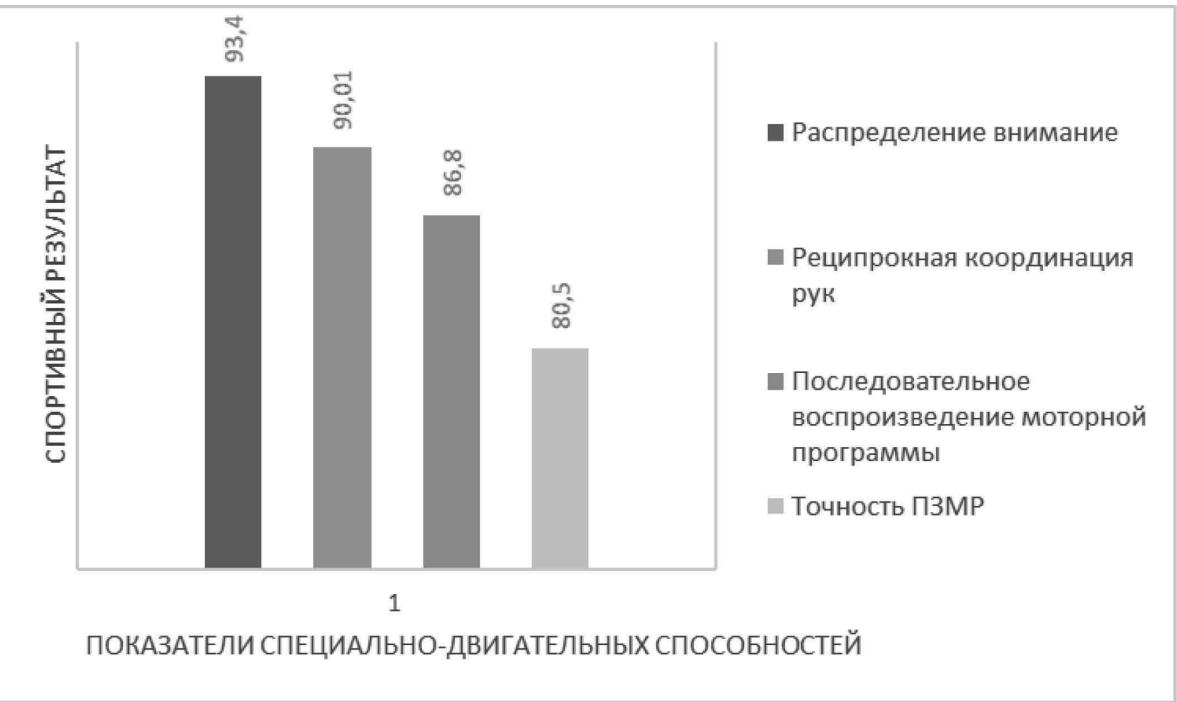

Рис. 1. - Показатели специально-двигательных способностей (\%) и их доля обобщенной дисперсии в описании спортивного результата. 
установил, что наибольшая доля дисперсии в описании спортивного результата и равная 93,4\% принадлежит показателю распределения внимания. Чем выше коэффициент распределения внимания у спортсменок, тем выше их спортивный результат. Коэффициент корреляции между спортивным результатом и показателем распределения внимания $\mathrm{r}=0.967$, а значит связь между исследуемыми признаками - прямая, теснота (сила) связи по шкале Чеддока - весьма высокая. Уравнение парной линейной регрессии: $y=-1.26415+1.03103 *$ х. Коэффициент детерминации r2 $=0.934$ (факторный признак х определяет 93.4\% дисперсии зависимого признака у). Средняя ошибка аппроксимации (характеризует адекватность регрессионной модели) составляет $31.5 \%$.

Менее выражена взаимосвязь между спортивным результатом и результатом в тесте на реципрокную координацию рук по пробе Н.И. Озерецкого. Коэффициент корреляции $r=-0.949$. Связь между исследуемыми признаками - обратная, теснота (сила) связи по шкале Чеддока - весьма высокая. Данное обстоятельство означает чем меньше серий движений, направленных на реципрокную координацию рук, смогла воспроизвести спортсменка, тем дальше от первого места расположен спортивный результат юной гимнастки. в турнирной таблице. Уравнение парной линейной регрессии: у = $19.62329-1.82842$ * х. Коэффициент детерминации r2 равен 0.901 (факторный признак х определяет 90.1\% дисперсии зависимого признака у). Средняя ошибка аппроксимации (характеризует адекватность регрессионной модели) составляет $18.2 \%$.

Далее представлена взаимосвязь между спортивным результатом и результатом в тесте, направленном на определение способности воспроизводить последовательно, заданную моторную программу по пробе Н.И. Озерецкого. Выявлено, что ниже способность воспроизводить последовательно, заданную моторную программу, тем дальше от первого места расположен спор- тивный результат юной гимнастки в турнирной таблице. Коэффициент корреляции (r) равен -0.932. Связь между исследуемыми признаками - обратная, теснота (сила) связи по шкале Чеддока - весьма высокая. Уравнение парной линейной регрессии: $y=23.40835-2.14923{ }^{*} \mathrm{x}$. Коэффициент детерминации r2 равен 0.863 (факторный признак х определяет 86.8\% дисперсии зависимого признака у). Средняя ошибка аппроксимации (характеризует адекватность регрессионной модели) составляет $23.9 \%$.

Наименьшая доля дисперсии в описании спортивного результата и равная 80,5 \% принадлежит показателю точности в простой зрительно-моторной реакции. Установлено, чем больше количество ошибок допущено в тесте на определение точности простой зрительно-моторной реакции с помощью специализированного ПО «Расклик», тем дальше от первого места расположен спортивный результат юной гимнастки в турнирной таблице. Коэффициент корреляции $\mathrm{r}=0.932$. Связь между исследуемыми признаками - прямая, теснота (сила) связи по шкале Чеддока - весьма высокая. Уравнение парной линейной регрессии: $y=-5.07471+2.54598 *$ х. Коэффициент детерминации r2 равен 0.805 (факторный признак $\mathrm{x}$ определяет $80.5 \%$ дисперсии зависимого признака у). Средняя ошибка аппроксимации (характеризует адекватность регрессионной модели) составляет $62.5 \%$

\section{Выво $\Delta ы$}

В результате исследования установлено, что у девочек в возрасте 9-10 лет, проходящих спортивную подготовку по виду спорта «художественная гимнастика» наибольшее влияние из исследуемых показателей специально-двигательных способностей принадлежит показателю распределения внимания. Полагаем, достоверным рассматривать данный показатель в качестве ведущего фактора, описывающего уровень развития специально-двигательных способностей и обуславливающий спортивный результат.

\section{ЛИТЕРАТУРА}

1. Бернштейн Н.А. 0 ловкости и ее развитии. - М.: ФиС, 1991

2. Балашова Е.Ю., Ковязина М.С. Нейропсихологическая диагностика в вопросах и ответах.-2-е изд., испр. и доп. (Учебник XXI века). — Генезис Москва, 2013. - C. 240.

3. Винер-Усманова И.А. Артистичность в художественной гимнастике: монография / И.А. Винер-Усманова. - Санкт-Петербург: Федеральное государственное автономное образовательное учреждение высшего образования «Санкт-Петербургский политехнический университет Петра Великого», 2012. - 91 с. ISBN 9785742237532.

4. Винер И.А. Взаимосвязь эстетических ценностей и зрительских впечатлений при исполнении соревновательных упражнений в гимнастических видах спорта / И.А. Винер, Р.Н. Терехина, М.А. Плеханова, А.М. Кабаева // Ученые записки университета им. П.Ф. Лесгафта. - СПб., 2009.

5. Вишнякова С.В. Особенности соревновательных композиций в технико-эстетических видах спорта (на примере эстетической гимнастики): уч. пос. / С.В. Вишнякова. - Волгоград: ВГАФК, 2012. - 132 с.

6. Дубровинская Н.В., Фарбер Д. А., М. М. Безруких М. М. Психофизиология ребенка. Психофизиологические основы детской валеологии: учеб. пособие для ВУзОВ - М.: ВЛАДОС, 2000. - 144 С. 
7. Карпенко Л.А. 0 выразительности, артистизме и эмоциональности в гимнастике // Термины и понятия в сфере физической культуры. СПб., 2007. С. 104-105

8. Краева Е.С. Совершенствование выполнения перебросок в групповых упражнениях в художественной гимнастике на основе развития специально-двигательных способностей у высококвалифицированных гимнасток: диссертация ... кандидата педагогических наук: 13.00.04 / Краева Елена Сергеевна. - Санкт-Петрбург, 2018. - 167с.

9. Микадзе Ю.В., Корсакова Н.К. Нейропсихологическая диагностика и коррекция младших школьников в связи с неуспеваемостью в школе. М.: ИнтелТех, 1994.64 C.

10. Поздеева Е.А. Моделирование оценки исполнительского мастерства спортсменов старших разрядов в спортивной аэробике / Е.А. Поздеева // Омский научный вестник. - 2006. - № 5 (39). - С. 250-253

11. Приказ Министерства спорта РФ от 20 августа 2019 г. № 675 «0б утверждении федерального стандарта спортивной подготовки по виду спорта «художественная гимнастика»

12. Смирнов Ю.И. Теория и методика оценки и контроля спортивной подготовленности : автореф. дис. ... д-ра пед. наук / Ю.И. Смирнов. - М., 1991. -37 с.

13. Силич Е.В. Индивидуализация психологической подготовки юных спортсменов в сложнокоординационных видах спорта: автореф. дис. ... канд. пед. наук: 13.00.04. - Минск, 2012. -28 с.

14. Тест 18. Определение уровня развития зрительно-моторной регуляции действий, моторной координации и ловкости («Пробы моторной одаренности» Н.И. Озерецкого) // Психологическая диагностика готовности к обучению детей 5-7 лет. - Волгоград : Издательство «Учитель», 2014. - С. 24.

15. Шувалова Л.С. Динамика показателей физического развития у девочек в возрасте 7 - 10 лет в художественной гимнастике // Современная наука: актуальные проблемы теории и практики. Серия: Гуманитарные науки. - 2021. - № 2. - C. 129-134. - D0I 10.37882/2223-2982.2021.02.39.

16. Шувалова Л.С. Мониторинг текущего состояния юных гимнасток в возрасте 9-10 лет с использованием специализированного программного обеспечения киберспортивной платформы Click-Storm / Л.С. Шувалова, Н.А. Родина, А.С. Талан // День спортивной информатики : Материалы IV Всероссийской научно-практической конференции, Москва, 04-05 декабря 2020 года. - Москва: Без издательства, 2020. - С. 100-103.

17. Шувалова Л.С. Развитие специально-двигательных способностей у девочек в возрасте 7 -10 лет как основа повышения качества исполнительского мастерства в групповых упражнениях художественной гимнастики // Современная наука: актуальные проблемы теории и практики. Серия: Гуманитарные науки. - 2021. - № 6-2. - С. 81-85. - D0I 10.37882/2223-2982.2021.06-2.27

18. Шуголь Е.А. Обоснование применения методики оценки динамического праксиса «проба Озерецкого» на начальном этапе подготовке в художественной гимнастике у девочек в возрасте 8 лет / Е.А. Шуголь, А.А. Соловьев // Становление психологии и педагогики как междисциплинарных наук : сборник статей по итогам Международной научно-практической конференции, Челябинск, 24 мая 2021 года. - Стерлитамак: Общество с ограниченной ответственностью «Агентство международных исследований», 2021. - С. 68-73.

○ Шувалова Лилия Сергеевна (lilia9292@mail.ru), Талан Алексей Сергеевич (alex@click-storm.com), Родина Наталья Александровна (rgforce@mail.ru), Кузнецов Евгений Валентинович (lera24122001@gmail.com). Журнал «Современная наука: актуальные проблемы теории и практики» 